\section{Stroke in a child with hemoglobin SC disease: a case report describing use of hydroxyurea after transfusion therapy}

\author{
Diana Fridlyand,'1 Caroline Wilder,1 \\ E. Leila Jerome Clay, ${ }^{1}$ Bruce Gilbert, ${ }^{2}$ \\ Betty S. Pace 1 \\ 1Department of Pediatrics and \\ 2Department of Radiology, Augusta \\ University, GA, USA
}

\begin{abstract}
Children with hemoglobin SC (HbSC) disease suffer a significant incidence of silent cerebral infarcts but stroke is rare. A 2-year-old African American boy with HbSC disease presented with focal neurologic deficits associated with magnetic resonance imaging evidence of cerebral infarction with vascular abnormalities. After the acute episode he was treated with monthly transfusions and subsequently transitioned to hydroxyurea therapy. The benefits of hydroxyurea as a fetal hemoglobin inducer in $\mathrm{HbSC}$ disease, to ameliorate clinical symptoms are supported by retrospective studies. This case highlights the rare occurrence of stroke in a child with $\mathrm{HbSC}$ disease and the use of hydroxyurea therapy.
\end{abstract}

\section{Introduction}

Sickle cell disease (SCD) is a group of inherited blood disorders caused by either homozygous mutations in the $\beta^{\mathrm{S}}$-globin gene producing hemoglobin $\mathrm{SS}(\mathrm{HbSS})$ or heterozygous alleles including $\mathrm{HbS} \beta^{0}$-thalassemia, $\mathrm{HbS} \beta^{+}$-thalassemia and $\mathrm{HbSC}$ disease. While sickle cell anemia (SCA), including $\mathrm{HbSS}$ and $\mathrm{HbS} \beta^{0}$-thalassemia, causes the most severe clinical phenotypes, children with $\mathrm{HbSC}$ and $\mathrm{HbS} \beta^{+}$-thalassemia can experience significant complications. ${ }^{1}$ In the United States and United Kingdom, $\mathrm{HbSC}$ represents approximately $30 \%$ of SCD patients, and accounts for more than $50 \%$ of SCD patients in West Africa. ${ }^{2}$ The phenotype of HbSC disease arises secondary to potentiation of hemoglobin S polymerization by the presence of hemoglobin $\mathrm{C}$ leading to cellular dehydration secondary to loss of water and potassium. ${ }^{3}$

The efficacy of hydroxyurea (HU) in reducing vaso-occlusive episodes in adults with SCA was demonstrated in the Multicenter Study of Hydroxyurea in Sickle
Cell Anemia,4 steering Food and Drug Administration approval. Subsequent studies showing efficacy and safety in children revolutionized care. The latest recommendation is that all children with SCA be offered HU starting at nine months of age, regardless of clinical symptoms. ${ }^{5}$ However, limited clinical trials make the management of children with $\mathrm{HbSC}$ and $\mathrm{HbS} \beta^{+}$-thalassemia less clear, although many experience a severe disease phenotype. ${ }^{6}$

Stroke occurs in $11 \%$ of children with sickle cell anemia, but chronic red blood cell transfusions decrease recurrence by $90 \% .^{7}$ In contrast, stroke is extremely rare in HbSC disease; however, $13.5 \%$ of children experience silent cerebral infarcts. ${ }^{8}$ The Stroke Prevention Trial in Sickle Cell Anemia (STOP) demonstrated the benefit of red cell transfusions in preventing strokes in children with Transcranial Doppler (TCD) velocities $>200 \mathrm{~mm} / \mathrm{sec}^{9}$ More recently, the Transcranial Doppler with Transfusions Changing to Hydroxyurea (TWiTCH) trial established the non-inferiority of substituting HU therapy for chronic transfusions in children with SCA and abnormal TCD, ${ }^{10}$ supporting its use in this population.

The most beneficial effect of HU is fetal hemoglobin $(\mathrm{HbF})$ induction, which inhibits $\mathrm{HbS}$ polymerization. ${ }^{11}$ Moreover, HU has anti-inflammatory, immune modulating, cell-signaling and gene transcription modifying effects. Consequently, we present a patient with HbSC disease with neurologic abnormality and cerebral infarction, and discuss the challenges of diagnosis and clinical management.

\section{Case Report}

\section{History and physical exam}

A 2 year old African American boy with $\mathrm{HbSC}$ disease was well until two years of age when he was admitted to the hospital for acute chest syndrome. A week after discharge, he was evaluated in the hematology clinic, at which point grandmother reported a week long history of dragging his right foot. His mother witnessed one episode of body stiffening without tonic-clonic movements and noted starring for a few seconds as well as less understandable speech. The neurology team was consulted and recommended magnetic resonance image and magnetic resonance arteriogram (MRI/MRA) studies and an electroencephalogram (EEG) after the history of a focal deficit was obtained. The MRI revealed abnormal T2 hyperintense signal within the bilateral peritrigonal white mat-
Correspondence: Betty S. Pace, Department of Pediatrics, Augusta University, 1120 15th Street, CN-4112, Augusta, GA 30912, USA

Tel.: +1.706.721.6893 - Fax: +1.706.721.0174

E-mail: bpace@augusta.edu

Key words: Hemoglobin SC disease, hydroxyurea, cerebral infarct, sickle cell anemia, hematology.

Acknowledgements: The authors would like to thank Judi Schweitzer for administrative assistance with data collection and the nurses in the hematology clinic and inpatient services for assisting with clinical management.

Contributions: DF designed the case report, collected data, and wrote the paper. $\mathrm{CW}$ reviewed the medical record, collected data on the case and contributed to writing and reviewing the paper. ELJC was involved with the diagnosis and clinical management and decision making to transition to hydroxyurea and assisted with writing and reviewing the paper. BG provided expertise for the MRI/MRA review and writing the paper. BSP supervised the overall experimental design and focus the case report and writing and editing paper.

Conflict of interest: the authors declare no potential conflict of interest.

Received for publication: 20 November 2016. Revision received: 16 February 2017. Accepted for publication: 17 February 2017

This work is licensed under a Creative Commons Attribution NonCommercial 4.0 License (CC BY-NC 4.0).

CCopyright D. Fridlyand et al., 2017

Licensee PAGEPress, Italy

Pediatric Reports 2017; 9:6984

doi:10.4081/pr.2017.6984

ter due to chronic ischemic change (Figure 1), consistent clinically with an ischemic stroke. The initial MRA noted possible minimal narrowing of the right carotid terminus and the origin of the left middle cerebral artery. The EEG was normal.

\section{Clinical management}

The child was admitted to the pediatric intensive care unit for a partial exchange transfusion with a baseline $\mathrm{HbS} 48.4 \%$, $\mathrm{HbC} 47.9 \%$ and $\mathrm{HbF} 3.7 \%$ (Table 1). Since his baseline hemoglobin was $10.6 \mathrm{gm} / \mathrm{dL}$, blood was removed $(100 \mathrm{~mL} ; 7 \mathrm{~mL} / \mathrm{kg})$ and $100 \mathrm{~mL}$ of sickle negative packed red cells were transfused producing a post $\mathrm{HbS}$ $36.7 \%$. A TCD was obtained which was normal by STOP criteria. ${ }^{9}$ Given the clinical history and MRI results, chronic transfusions were recommended to maintain 
$\mathrm{HbS}<30 \%$ for stroke prevention. Due to an average $\mathrm{HbS} 40 \%$ and hemoglobin 11.6 $\mathrm{gm} / \mathrm{dL}$, pre-transfusion phlebotomies were performed. Coagulation studies including protein $\mathrm{C}$, protein $\mathrm{S}$, antithrombin III, prothrombin, Factor V Leiden, and lupus anticoagulant were normal. Echocardiogram was obtained which demonstrated a structurally normal heart. After 6 months of transfusions, a repeat MRI and MRA were performed and showed no interval change. While on transfusions symptoms resolved and his speech returned to normal, which was confirmed by joint hematology and neurology follow-up. Based on clinical improvement and studies which demonstrated clinical and laboratory efficacy of HU use in HbSC patients, ${ }^{12-14}$ the decision was made to transition the child from chronic transfusions to HU $300 \mathrm{mg}$ (22.2 $\mathrm{mg} / \mathrm{kg}$ /day). During therapy he had a decrease in white blood cell count from 8.2 to 6.5 cells $/ \mu \mathrm{L}$, absolute neutrophil count from 5576 to $2925 \times 109 / \mathrm{L}$, and platelet counts ranged from 267,000 to $154,000 / \mathrm{mm}^{3}$. Of note, total hemoglobin increased from 9.4 to $11.3 \mathrm{~g} / \mathrm{dL}, \mathrm{MCV}$ from 78.6 to $90.9 \mathrm{fL}$ and $\mathrm{HbF}$ from $3.7 \%$ to $5.1 \%$. He has continued to do well without reoccurrence of clinical symptoms for two years and a repeat TCD remained normal after 6 months of HU therapy.

\section{Discussion and Conclusions}

Data from the Cooperative Study of Sickle Cell Disease (CSSCD) has provided substantial information regarding the natural history of HbSC disease. ${ }^{6}$ The large, multi-institutional study demonstrated 0.8 pain episodes per patient-year in $\mathrm{HbSS}$ compared to 0.4 episodes per patient-year in HbSC. ${ }^{6}$ By age 3, 32\% of Hb SC infants had abnormal pocked red blood cell counts, with intermediate splenic dysfunction. ${ }^{6}$ The rate of osteonecrosis did not differ significantly between $\mathrm{HbSS}$ and $\mathrm{HbSC}$ patients, and the incidence of acute chest syndrome in $\mathrm{HbSC}$ patients was 5.2 per 100 patient years. ${ }^{6}$ Additionally, children with $\mathrm{HbSS}$ and $\mathrm{HbSC}$ had the highest rates of bacteremia under the age of 2 years. ${ }^{6}$

The coagulation workup in our case study did not show abnormalities; however, germane to our report is the role of hypercoagulation in the clinical manifestations of $\mathrm{HbSC}$ disease. Data in children are limited but findings of a cross-sectional observational study support increased risk of thromboembolic events in adults with HbSC disease. ${ }^{15}$ There was observed increased expression of tissue factor, thrombin-antithrombin complex and D-dimer when compared to healthy controls, but levels in HbSC patients were lower than those in SCA patients. ${ }^{15}$ The higher hemolytic activity and inflammation observed in HbSC patients were associated with retinopathy and osteonecrosis. ${ }^{15}$

Given a paucity of data regarding management of patients with $\mathrm{HbSC}$ disease, studies in patients with SCA have been employed in clinical decisions. Numerous clinical trials in adults and children 16,17 have demonstrated the benefit of HU in reducing the clinical severity of SCA by decreasing dactylitis, acute chest syndrome, and hospitalization rates. ${ }^{17}$ However, stroke continued to be a common complication in SCA with significant morbidity before chronic transfusions and TCD screen were established as standard of care. ${ }^{7}$ The long-term complication of iron overload prompted studies to determine whether $\mathrm{HU}$ is an effective alternative. The Sparing Conversion to Abnormal TCD Elevation study demonstrated the efficacy of $\mathrm{HU}$ in children with SCA and conditional TCD velocities (170-199 cm/sec). ${ }^{18}$ More recently, the TWiTCH trial demonstrated children without vasculopathy on MRA could be treated with HU after a year of transfusion therapy. 10

The major effect of HU is $\mathrm{HbF}$ induction by mechanisms including inhibition of ribonucleotide reductase and DNA synthesis leading to cell death ${ }^{19}$ and rapid maturation of erythroid progenitors; 20 similarly, $\mathrm{HU}$ has been demonstrated to increase $\mathrm{HbF}$ in $\mathrm{HbSC}$ patients. ${ }^{12-14}$ Hydroxyurea also acts as a nitric oxide (NO) donor to activate cyclic guanosine monophosphate 21 and enhanced $\gamma$-globin gene expression by transcription factors such as cJun. 22 Since NO depletion due to chronic hemolysis in SCA

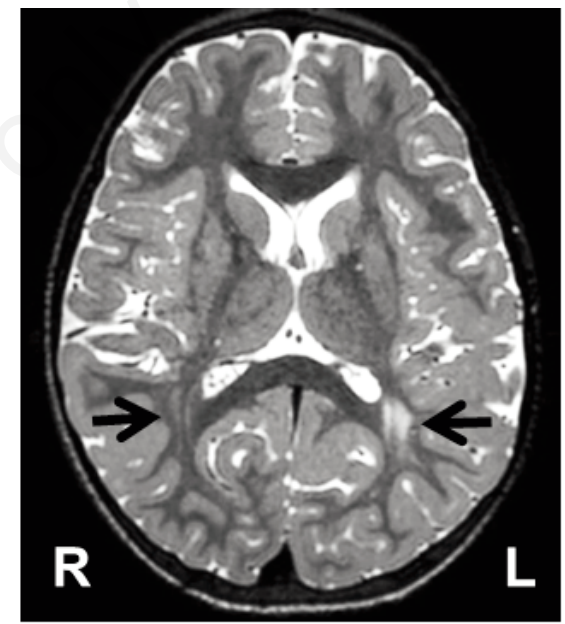

Figure 1. Magnetic resonance imaging demonstrates chronic deep white matter ischemia. Standard T2 weighted imaging was performed under sedation which showed abnormal T2 hyperintense signal (arrows) within the bilateral peritrigonal white matter (left greater than right).

Table 1. Summary of laboratory and imaging tests results.

\begin{tabular}{|c|c|c|c|c|}
\hline Laboratory / imaging test & Baseline & $\begin{array}{l}\text { Chronic transfusions } \\
\text { 4th months }\end{array}$ & $\begin{array}{l}\text { Before start of } \\
\text { hydroxyurea }\end{array}$ & $\begin{array}{l}\text { After } 1 \text { year on } \\
\text { hydroxyurea }\end{array}$ \\
\hline $\mathrm{HbS}(\%)$ & 48.4 & 28.2 & 25.4 & 49.4 \\
\hline $\mathrm{HbC}(\%)$ & 47.9 & 25.8 & 21.7 & 41.8 \\
\hline $\operatorname{HbF}(\%)$ & 3.7 & 3.2 & 2.9 & 5.1 \\
\hline White blood cells $(/ \mu \mathrm{L})$ & 8.2 & 13.5 & 12.9 & 6.5 \\
\hline Neutrophils $(\times 109 / \mathrm{L})$ & 5576 & 8505 & 6,708 & 2,925 \\
\hline Hemoglobin (gm/dL) & 9.4 & 11.3 & 11.3 & 10.8 \\
\hline Platelets $\left(\mathrm{mm}^{3}\right)$ & 267,000 & 233,000 & 240,000 & 154,000 \\
\hline Mean corpuscular volume (fL) & 78.6 & 78.5 & 79.7 & 90.9 \\
\hline Magnetic resonance imaging & Abnormal & & Unchanged & \\
\hline Magnetic resonance arteriogram & Abnormal & & Normal & \\
\hline Computed tomography & Normal & & Normal & Normal \\
\hline Electroencephalogram & Normal & & & \\
\hline
\end{tabular}


contributes to the development of vasculopathy, HU reverses this effect by improving NO levels and blood flow, and decreasing endothelial activation and neutrophil adhesion to molecules such as fibronectin and intercellular adhesion molecule 1.23 Another beneficial effect of $\mathrm{HU}$ is its ability to decrease the elevated white blood cell counts associated with early death, stroke and acute chest syndrome in $\mathrm{SCA}^{24}$ and $\mathrm{HU}$ has been demonstrated to reduce white blood cell count and absolute neutrophil count in HbSC patients as well. ${ }^{12}$ However, bone marrow suppression producing neutropenia and thrombocytopenia are limitations of HU therapy, and thrombocytopenia has led to discontinuation of therapy in HbSC patients. ${ }^{13}$

The role of HU therapy in $\mathrm{HbSC}$ patients is less clear because this population has been excluded from major clinical trials. Data from the CSSCD established a $5.6 \%$ rate for silent cerebral infarct in SCD. ${ }^{6}$ Using more contemporary MRI/MRA techniques, the rate ranges from $13.5-16 \%{ }^{8}$ but overt stroke remains a rare complication. While HbSC disease generally produces a less severe clinical phenotype than SCA, our case demonstrates stroke can occur. Given the challenges of chronic red cell transfusions in this population, alternative therapy is needed. Recent single institution retrospective studies involving $\mathrm{HbSC}$ patients ${ }^{25}$ suggest $\mathrm{HU}$ reduces pain crises making it a feasible option. Data from a multicenter retrospective study of several $\mathrm{HbSC}$ cohorts support the ability of HU to increase $\mathrm{HbF}$ and decrease white cell counts without severe bone marrow suppression in adults and children to produce a beneficial effect. ${ }^{12,14}$ Limited studies have been conducted to address treatment options for $\mathrm{HbSC}$ disease. Future prospective studies are required to validate $\mathrm{HU}$ as a treatment option for children with $\mathrm{HbSC}$ disease with severe clinical complications including stroke.

\section{References}

1. Ballas SK, Lieff S, Benjamin LJ, et al. Definitions of the phenotypic manifestations of sickle cell disease. Am J Hematol 2010;85:6-13.

2. Pecker LH, Schaefer BA, LuchtmanJones L. Knowledge insufficient: the management of haemoglobin SC dis- ease. Br J Haematol 2017; 176:515-26.

3. Nagel RL, Fabry ME, Steinberg MH. The paradox of hemoglobin SC disease. Blood Rev 2003;17:167-78.

4. Charache S, Terrin ML, Moore RD, et al. Effect of hydroxyurea on the frequency of painful crises in sickle cell anemia. Investigators of the Multicenter Study of Hydroxyurea in Sickle Cell Anemia. N Engl J Med 1995;332:131722.

5. Buchanan GR, Yawn BP, Afenyi-Annan AN, et al. Evidence-based management of sickle cell disease. Expert Panel Report, 2014. US Department of Health and Human Services; National Heart, Lung, and Blood Institute. Available from: https://www.nhlbi.nih.gov/ sites/www.nhlbi.nih.gov/files/sicklecell-disease-report.pdf

6. Bonds DR. Three decades of innovation in the management of sickle cell disease: the road to understanding the sickle cell disease clinical phenotype. Blood Rev 2005;9:99-110.

7. Adams RJ, McKie VS, Hsu L, et al. Prevention of a first stroke by transfusions in children with sickle cell anemia and abnormal results on transcranial doppler ultrasonography. N Engl J Med 1998;339:5-11.

8. Guilliams KP, Fields ME, Hulbert ML. Higher-than-expected prevalence of silent cerebral infarcts in children with hemoglobin SC disease. Blood 2015;125:416-7.

9. Adams RJ, McKie VC, Brambilla D, et al. Stroke prevention trial in sickle cell anemia. Control Clin Trials 1998;19: 110-29.

10. Ware RE, Davis BR, Schultz WH, et al. Hydroxycarbamide versus chronic transfusion for maintenance of transcranial doppler flow velocities in children with sickle cell anaemia-TCD With Transfusions Changing to Hydroxyurea (TWiTCH): a multicentre, open-label, phase 3, non-inferiority trial. Lancet 2016;387:661-70.

11. Steinberg MH, Chui DHK, Dover GJ, et al. Fetal hemoglobin in sickle cell anemia: a glass half full? Blood 2014;123:481-5.

12. Luchtman-Jones L, Pressel S, Hilliard $\mathrm{L}$, et al. Effects of hydroxyurea treatment for patients with hemoglobin SC disease. Am J Hematol 2016;91:238-42.

13. Yates AM, Dedeken L, Smeltzer MP, et al. Hydroxyurea treatment of children with hemoglobin SC disease. Pediatr Blood Cancer 2013;60:323-5.

14. Miller MK, Zimmerman SA, Schultz WH, Ware RE. Hydroxyurea therapy for pediatric patients with hemoglobin SC disease. J Pediatr Hematol Oncol 2001;23:306-8.

15. Colella MP, de Paula EV, MachadoNeto JA, et al. Elevated hypercoagulability markers in hemoglobin SC disease. Haematologica 2015;100:466-71.

16. Hankins JS, Ware RE, Rogers ZR, et al. Long-term hydroxyurea therapy for infants with sickle cell anemia: the HUSOFT extension study. Blood 2005; 106:2269-75.

17. Thornburg CD, Files BA, Luo Z, et al. Impact of hydroxyurea on clinical events in the BABY HUG trial. Blood 2012;120:4304-10.

18. Hankins JS, McCarville MB, RankineMullings A, et al. Prevention of conversion to abnormal transcranial Doppler with hydroxyurea in sickle cell anemia: a phase III international randomized clinical trial. Am J Hematol 2015;90: 1099-105.

19. Ware RE. How I use hydroxyurea to treat young patients with sickle cell anemia. Blood 2010;115:5300-11.

20. Ho JA, Pickens CV, Gamcsik MP, et al. In vitro induction of fetal hemoglobin in human erythroid progenitor cells. Exp Hematol 2003;31:586-91.

21. King SB. A role for nitric oxide in hydroxyurea-mediated fetal hemoglobin induction. J Clin Invest 2003;111: 171-2.

22. Kodeboyina S, Balamurugan $\mathrm{P}$, Liu L, Pace BS. cJun modulates Ggamma-globin gene expression via an upstream cAMP response element. Blood Cells Mol Dis 2010;44:7-15.

23. Canalli AA, Franco-Penteado CF, Saad ST, et al. Increased adhesive properties of neutrophils in sickle cell disease may be reversed by pharmacological nitric oxide donation. Haematologica 2008;93:605-60.

24. Platt OS, Brambilla DJ, Rosse WF, et al. Mortality in sickle cell disease. Life expectancy and risk factors for early death. N Engl J Med 1994;330:1639-44.

25. Lebensburger JD, Patel RJ, Palabindela $\mathrm{P}$, et al. Hydroxyurea decreases hospitalizations in pediatric patients with $\mathrm{Hb}$ $\mathrm{SC}$ and $\mathrm{Hb} \mathrm{SB}+$ thalassemia. J Blood Med 2015;15:285-90. 